\section{Exact SciencePark Research, Organization \& Counseling \\ International Journal of Learning and Teaching}

Volume 08, Issue 1, (2016) 61-68

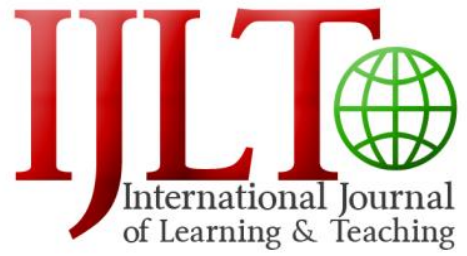

http://sproc.org/ojs/index.php/ijlt

\title{
Investigating pre-service science teachers' laboratory approach choices
}

\author{
Nurhan Ozturk ${ }^{*}$, Sinop University, Faculty of Education, Department of Science Education, Sinop, Turkey \\ Esra Bozkurt Altan, Sinop University, Faculty of Education, Department of Science Education, Sinop, Turkey \\ Serhat Ercan, Sinop University, Faculty of Education, Department of Science Education, Sinop, Turkey
}

\section{Suggested Citation:}

Ozturk, N., Bozkurt Altan, E. \& Ercan S. (2016). Investigating pre-service science teachers' laboratory approach choices. International Journal of Learning and Teaching. 8(1), 61-68.

Received November 05, 2015; revised December 19, 2015; accepted January 01, 2016;

Selection and peer review under responsibility of Prof. Dr. Hafize Keser, Ankara University, Ankara, Turkey.

${ }^{\circ} 2016$ SciencePark Research, Organization \& Counseling. All rights reserved.

\begin{abstract}
The main focus of the current study was to determine what kind of laboratory approaches will be designed how this process will be evaluated by pre-service teachers. The study was carried out on the basis of a qualitative paradigm. The study group of the research consisted of 40 pre-service science teachers. In the current study, the application was conducted within the Laboratory Applications in Science I-Il courses at two stages. The per stage was conducted in 14 weeks (four hours per weeks). The first stage of the process (14 weeks) started with a theoretical presentation introducing laboratory approaches and was conducted with the guidance of five experiment manuals designed on the basis of different laboratory approaches ranging from a confirmatory laboratory approach to an inquiry-based learning by the researcher. In the second stage, the pre-service teachers were asked to examine the units and objectives of the Science Curriculum Program and then were asked to select a laboratory approach and set the objectives to design an activity manual. The pre-service teachers worked for five weeks to determine the objectives, find the appropriate approach and design an experiment manual in line with the selected approach. Then, each group conducted the laboratory class under the guidance of their experiment manual that they had developed for each week. The data of the study was collected within two periods through the difficulties experienced, skills attained through the process, reflective texts presenting course-related suggestions and semi-structured interviews. It was determined that the students experienced some difficulties in the selection of the laboratory approach for the given topic and the design of experiment manuals; they preferred inquiry-based learning laboratory activities as they were believed to be more effective and administration of experiment manuals to peers were believed to be conducive to professional development.
\end{abstract}

Keywords:Laboratory applications in science, laboratory approaches, pre-service science teachers

* ADDRESS FOR CORRESPONDENCE: Nurhan Ozturk, Sinop University, Faculty of Education, Department of Science Education, Sinop, 57000 Turkey. E-mail address: nurhanozturk41@gmail.com / Tel.: +903682715526 (2036) 
Ozturk, N., Bozkurt Altan, E. \& Ercan S. (2016). Investigating pre-service science teachers' laboratory approach choices. International Journal of Learning and Teaching. 8(1), 61-68.

\section{Introduction}

The most important feature differentiating natural sciences from other sciences is that they are based on experiments and observations and they improve students' research skills by allowing them to discover and inculcate the skills of hypothesis construction and data interpretation in students (Balagun \& Odubunni, 1991). As natural sciences attach great importance to observation and experiment, laboratory activities are of great importance in imparting many skills and competencies to students (Donelly, 1998). Laboratory applications make important contributions to students' construction of their own knowledge in their minds, to the development of their problem solving and psychomotor skills and they can positively affect their attitudes towards the natural sciences (Azizoglu \& Uzuntiryaki, 2006; Domin, 1999a; Hofstein, 2004; Singer, Hilton \& Schweingruber, 2005). In addition, laboratory activities provide opportunities for students to be involved in the process to enhance their cooperation and communication skills (Domin, 1999b; Hofstein \& Lunetta, 2004). Given that laboratory activities are not conducted properly, adequately and effectively in various researches (Akar, 2006; Alpaut, 1993; Akdeniz et al., 1995; Akgun, 1995; Ayas et al., 1994; Ekici, 1996; Erten, 1991; Gurdal, 1991), implementation of laboratory activities that serve the intended purposes depend on the training of teachers who are qualified enough to conduct these activities (Gunes, Gunes \& Hoplan, 2012). However, the attainment of the desired objectives through laboratory activities (critical thinking, problem solving, development of scientific process skills, etc.) is closely associated with the activity types, which are preferred and the laboratory approaches that are adopted by teachers.

In this respect, the laboratory experiences gained by teachers during their pre-service education and opportunities to be offered to them to develop their questioning, problem solving, critical thinking (Lawson, 1995; Serin, 2002) and a series of scientific process skills, may contribute to their performance in laboratory settings during their professional career (Bybee, 2000; Hofstein, LeviNahum \& Shore, 2001). While laboratory activities are carried out to prove the accuracy of the previously learned scientific information, in recent years, laboratory settings have been considered to be environments in which students can discover information and more inquiry-based learning occurs (Hofstein \& Lunetta, 1982). In laboratory environments, the student's management of the process and investment of efforts to understand the phenomenon under investigation are believed to contribute to the realization of meaningful learning (Hofstein, 2004), which will help enable students to develop positive attitudes towards the laboratory and to strengthen their social relationships by developing their communication skills (Lazarowitz \& Tamir, 1994). In addition to this, laboratory environments play an important role in terms of students' participating in the process, being active in many skilled areas, such as researching, questioning, data collection and interpretation and feeling involved in the process at each stage (Jenkins, 1999). In this context, the main focus of the current study was to determine what kind of process will be designed, which approaches will be adopted and how this process will be evaluated by pre-service teachers who have been involved in applications, based on various laboratory approaches, while planning a laboratory process for themselves. In this regard, it was important to conduct this as a student-centered process to collect the pre-service teachers' opinions about the process and to reveal the efficiency of the application through their reflections on their experiences.

\section{Method}

In this study aimed to evaluate the process in which the pre-service teachers, who were involved in laboratory activities, drew on various laboratory approaches (deductive approach, inquiry based learning, design based learning) and plans and conducted the application process by selecting a laboratory approach on the basis of their perceptions, experiences and opinions. The current study was conducted qualitative paradigm. 
Ozturk, N., Bozkurt Altan, E. \& Ercan S. (2016). Investigating pre-service science teachers' laboratory approach choices. International Journal of Learning and Teaching. 8(1), 61-68.

\subsection{Study Group}

The study group of the current study consisted of 40 pre-service teachers (10 male, 30 female) attending the department of science education of a state university. In this program, students take Laboratory Applications in Science I-II courses in the fifth and sixth terms.

\subsection{Context of the Study}

In the current study, the implementation was conducted within the Laboratory Applications in Science I-Il courses at two stages. The per stage was conducted in 14 weeks (four hours per weeks).

The first stage (Laboratory Applications in Science I) was initiated with a theoretical presentation to introduce laboratory approaches. According to Leach (1999) and Ryder, Leach and Driver (1999), individuals, including undergraduate students, might not conceptualize what the role of experiments in natural sciences was, how they were conducted and what their importance was. Therefore, there was a need for preparation before starting the experimental process to inform the pre-service teachers about the concepts and procedures involved. In the theoretical presentation, the laboratory was taken as a context and the laboratory approaches were introduced to the participants. Suitable examples for each approach were presented to the students and the content of the course was explained. The course was conducted under the guidance of five experiment document prepared by the researchers, who were also teaching the course, on the basis of different approaches ranging from a confirmatory approach to an inquiry-based learning approach. The pre-service teachers examined each file in relation to the related approach in groups of four and thus the first stage ended.

In the second stage (Laboratory Applications in Science II), the participants were first asked to investigate the units and objectives stated in the Science Curriculum Program and to determine the objectives to be used in the preparation of an activity file, by selecting a laboratory approach. This again was held in groups of four. Meanwhile, each group was provided with access to the Internet and suitable resources. The pre-service teachers conducted tasks to set their objectives, to determine the suitable approach and to develop the experiment files, according to their selected approach. In the first week, they examined the units and objectives of the science curriculum program to determine the scope of the experiment files. Thus, they acquired some prior information. In the second week, they determined a laboratory approach and objectives to prepare the experiment files. The remaining three weeks were spent on the design of activity files and the determination of their content by considering their visual quality and compliance with the selected approach. Following the stages of theoretical presentation and pre-planning, the application stage, in which each group would conduct laboratory courses of the week in line with the experiment files they had developed, was initiated. In this application stage, the groups took the role of the conductor of the class and carried out the process in line with the approach they had selected. The group members assumed different responsibilities, such as directing the groups, making contact with them, supplying necessary equipment and tools and presenting the required conceptual information. Meanwhile, the researchers did not intervene with the process, which was carried out by the conductors of the class.

\subsection{Data Resources and Analysis}

The data of the current study was collected through writing texts (including the suggestions of the participants regarding the course) and semi-structured interviews conducted at the end of the implementation The pre-service teachers' reasons for selecting their preferred approach, the differences between their instructional process design and its actual application and the extent to which they were content with the feedback given by their peers were investigated by means of semistructured interviews. In addition to this, the written and oral evaluations of the other groups 
regarding the performance of the group conducting the experimental process (group management, selecting the appropriate approach, the interruptions, if any, in the process and positive aspects of the process, etc.) were also used a source of data.

The data of the study was qualitatively analyzed. During the analysis process, a comparative evaluation of the concepts and expressions repeated in the answer of each individual was conducted and, thus, a coding system was established. For each participant, a code name was given (e.g., OA1) in their reflective texts and interviews and a code-theme list was prepared.

The coding was performed sometimes in the form of words, sometimes in the form of sentences and sometimes in the form of phrases. By reviewing the first coding, it was simplified by renaming the similar codes and a shorter list of codes was attained (Bogdan \& Biklen, 2007; Gay, Mills \& Airasian, 2006). After that, the participants' responses were revised and their frequencies were determined. In the last stage, the codes were classified and combined under certain categories (Creswell, 2005; Maxwell, 2005; Strauss \& Corbin, 1998).

One category was obtained during the data analysis process and the codes, which were gathered under this category, are presented in Table 1.

Table 1. Sample Category and Codes

\begin{tabular}{ll}
\hline Category & Code \\
\hline & Lack of information \\
& Preparation of the file \\
& Laboratory approach \\
& Topic selection \\
& The number of people in the group \\
\hline
\end{tabular}

How the codes were constructed as a result of the pre-service teachers' responses and presented in Table 1 is exemplified below:

Sample category: Difficulties experienced

Sample code: Laboratory approach

\section{Student response:}

"...First, we had great difficulty in deciding which approach to select because we had to determine its content according to the approach we would select. Though it was difficult to select the approach and prepare an activity file according to it, the following stages were relatively easier .... (PS8)"

\section{Findings}

The themes obtained as a result of the analysis of the pre-service teachers' evaluations and the categories subsumed under these themes are presented in Table 2. 
Ozturk, N., Bozkurt Altan, E. \& Ercan S. (2016). Investigating pre-service science teachers' laboratory approach choices. International Journal of Learning and Teaching. 8(1), 61-68.

Table 2. The Pre-service Teachers' Opinions about the Process

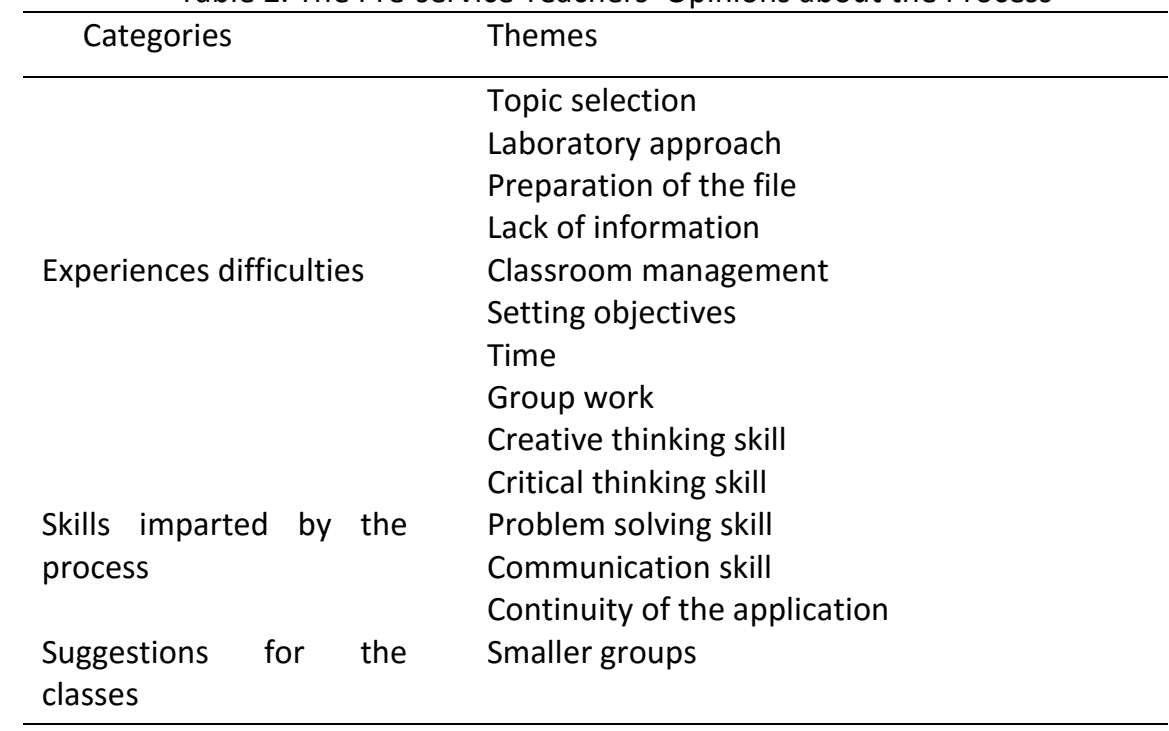

As can be seen in Table 2, the pre-service teachers' opinions about the process were collected under three categories. First, it was determined that most of them experienced some difficulty in topic selection $(f=18)$ and determination of the laboratory approach $(f=14)$. In a similar manner, the researchers' observations confirmed that the pre-service teachers experienced the greatest difficulty in topic selection and determination of the laboratory approach. Moreover, a considerable number of pre-service teachers $(f=10)$ stated that they experienced difficulty while preparing the activity file. The participants stated that within the framework of the Laboratory Applications in Science I course, they used the already-prepared file of the course, which was given by the teacher and, thus, they did not know how to prepare an activity file. As a result, they experienced problems in the determination of the suitability of the activity files for the selected approach. The other reasons stated by the preservice teachers for the difficulties experienced ranged from a lack of information about the selected topics to group work. The participants also stated that at the root of the difficulties they experienced was the fact that they had never been involved in such a process before and because they had to conduct all the phases of the application, they felt great responsibility. The opinions of a few preservice teachers about the difficulties experienced are as follows:

"We talked and discussed with my group members during the topic and approach selection processes. As we did not have enough information about these processes, we experienced great difficulties. We had much theoretical information but we were not much experienced about application ..." (PT21)

"I had some difficulties in this process as I did not have enough experience and practice. I experienced particular difficulty in deciding which topic and approach to select. I enjoyed the file preparation process. Another thing I found difficult was the classroom management ..."(PT12)

Though the pre-service teachers experienced many problems during the process, they believed that through this process, they gained many skills. A considerable number of the pre-service teachers $(f=22)$ believed that their communication skills had improved and some of them $(f=14)$ thought that their creative thinking skills had improved during the process. The continuous communication of the pre-service teachers within their groups, their becoming active in every stage of the application, the 
Ozturk, N., Bozkurt Altan, E. \& Ercan S. (2016). Investigating pre-service science teachers' laboratory approach choices. International Journal of Learning and Teaching. 8(1), 61-68.

obligation they felt to be involved in every situation they faced, their attempts to find solutions in cooperation and within-group discussions may have provided some opportunities for the participants to acquire some new skills. This assumption seems to be supported by the researchers' observation of each group during the process. Related opinions of one pre-service teacher are given below:

"During the application, we continuously discussed about how to generate new ideas because we wanted our activity file to be different. We spent many hours thinking about the problem statement of the activity..."(PT23)

The pre-service teachers made some suggestions about this process conducted in the laboratory course. A considerable number of the pre-service teachers $(f=28)$ proposed that, in the future, they should be the conductors of the laboratory applications and some of them $(f=14)$ proposed that decreasing the number of group members would be good. The participants also thought that their active involvement in the process should be continued. Though the pre-service teachers indicated that the process of the application was difficult, they may have made these suggestions as a result of the skills attained during the process. In this connection, the researcher observed some clues indicating that the pre-service teachers felt more comfortable when they were the conductors of the process; unlike in a traditional laboratory. Based on the suggestions made by the pre-service teachers for decreasing the number of members in the group, it might be concluded that the participants thought that classroom management by four students is difficult to handle and that they experienced some problems in preparing activity files and distribution of the tasks between the group members. In a similar way, the researchers also observed that some groups were confronted with problems due to the number of group members. A related opinion of one student is given below:

"... while preparing the activity file, we did not face any problems, but when it came to the application phase, we experienced some problems in the classroom management. If the number of the students in the group was lower, we would be able to conduct our activity more comfortably..."(PT17)

The semi-structured interviews conducted with the pre-service teachers revealed that while the students were determining the approach, which complied with their selected topic, they created connections with the topic to identify the approach. Six groups of ten were observed to have adopted the inquiry-based learning approach. These groups explained the reasons for their selection as follows: the most suitable approach for the topic they selected was the inquiry-based learning approach. With this approach, students could be engaged in an inquiry process from the beginning to the end of the application and starting the activity with a problem statement kept the students active. The preservice teachers also stated that the design of the process was not easy; however, their involvement in the process contributed to their self-confidence. The participants, who were the conductors of the activity files they had designed, stated that their management of the whole process resulted in their acquiring many skills and they were engaged in an application, which was quite distant from rote learning. When they compared the classes conducted on the basis of activity files externally imposed on them and the classes conducted on the basis of the activity files they themselves had developed, they stated that they should be the conductors of the classes with their own activity files. After implementing their activity files, each group collected feedback from the other groups in relation to the suitability of the approach, the management of the process, the information conveyed and the planning of the process in compliance with the approach. During the interviews, the pre-service teachers stated that as well as positive feedback, they also received negative feedback from their peers. They also believed that their peers' feedback provided some clues for them to notice the points that they had missed during the process. The participants stated that, as a result of this peer evaluation process, they were able to conduct self-evaluation within the group and made some suggestions for their group members. 
Ozturk, N., Bozkurt Altan, E. \& Ercan S. (2016). Investigating pre-service science teachers' laboratory approach choices. International Journal of Learning and Teaching. 8(1), 61-68.

\section{Discussion and Results}

The findings revealed that the pre-service teachers demonstrated positive attitudes towards the process, due to the skills they had attained, in spite of the difficulties they had experienced during the process. Turgut et al. (2012) found that though the pre-service teachers encountered some difficulties in the implementation of the laboratory model during the process, they evaluated the model positively. The pre-service teachers, trying to create connections between theory and practice while managing the process, stated that an applied learning environment was useful for both themselves and their peers. For an effective laboratory application to occur students need to establish links between theory and practice and, thus, their cognitive development can be promoted (Jalil, 2006). During the process, the pre-service teachers were determined to have experienced some problems in terms of the selection of a suitable approach, lack of information, classroom management, setting of objectives, time and the number of group members. On the other hand, they maintained that they had developed some new skills (creative thinking, critical thinking, problem solving and communication). Parallel to this finding, Turgut et al. (2012) reported the development of similar skills. The pre-service teachers made suggestions for the continuation of this application in the future and to decrease the number of group members. It was also determined that, while selecting a suitable laboratory approach, the participants created connections with the topic they had determined and managed the process as required by the respective laboratory approach. It was concluded that the pre-service teachers thought that the teaching process included a lot of information, skills and advantages for them. Finally, they stated that they felt content with the feedback given by their peers and, thus, they could also conduct self-evaluations.

\section{References}

Akar, E. O. (2006). Farkli turde okullarda calisan biyoloji ogretmenlerinin mesleki gelisim deneyim ve ihtiyaclari. Hacettepe Universitesi Egitim Fakultesi Dergisi, 30,174-183.

Akdeniz, A. R., Cepni, S., \& Azar, A. (1998). Fizik ogretmen adaylarının laboratuvar kullanimi becerilerini gelistirmek icin bir yaklasim, III. Ulusal Fen Bilimleri Egitimi Sempozyumu, Trabzon.

Akgun, S. (1995). Fen bilgisi ogretimi (5. Baskı), Ankara.

Alpaut, O. (1993). Fen egitiminin verimli ve islevsel hale getirilmesi. Ortaogretim Kurumlarinda Fen Ogretimi ve Sorunlari Sempozyumu, TED, Ankara.

Ayas, A., Cepni, S., \& Akdeniz, A.R. (1994). Fen bilimleri egitiminde laboratuarin yeri ve onemi; tarihsel bir bakıs. Cagdas Egitim Dergisi, 204, 21-25.

Azizoglu, N., \& Uzuntiryaki, E. (2006). Kimya laboratuvari endise olcegi. Hacettepe Universitesi Egitim Fakultesi Dergisi, 30, 55-62.

Balagun, T.A., \& Odubunni, O. (1991). The effect of lecture teaching methods on cognitive achievement in integrated science. Journal Research in Science Teaching, 28, 213-224.

Bogden, R. C., \& Biklen, S. K. (2007). Qualitative research for education: An introduction to theories and methods. Boston: Allyn\& Bacon.

Bybee, R. (2000). Teaching science as inquiry. In J. Minstrel \& E. Van Zee (Eds.), Inquiring into inquiry learning and teaching in science (pp. 20-46). Wasington, DC: American Association for the Advancement of Science.

Creswell, J. W. (2005). Educational research: Planning, conducting, and evaluating quantitative and qualitative research. Upper Saddle River, NJ: Pearson Education, Inc.

Domin, D.S., (1999a). A Content Analysis of General Chemistry Laboratory Manuals for Evidence of Higher-Order Cognitive Tasks, Journal of Chemical Education, 76(1), 109-111.

Domin, D. S. (1999b). A review of laboratory instruction styles. Journal of Chemical Education, 76(4), 543-547.

Donelly, J. F. (1998). The place of the laboratory in secondary science teaching. International Journal of Science Education, 20(5), 585-596.

Ekici, G. (1996). The aim of this study is to determine the methods used by biology teachers education and the problems they experience (Unpublished master thesis). Ankara University, Ankara. 
Erten, S. (1991). Biyoloji laboratuarlarının onemi ve laboratuarda karsılasılan guclukler (Unpublished master thesis). Gazi University, Ankara.

Gay, L. R., Mills, G. E., \& Airasian, R. (2006). Educational research: Competencies for analysis and applications (8th ed). Upper Saddle River, NJ: Pearson/Merrill/Prentice Hall.

Gunes, M. H., Gunes, O., \& Hoplan, M. (2012). Fen bilgisi ogretmen adaylarının fen bilgisi laboratuvar uygulamaları I-II dersine yonelik gorusleri. Journal of Educational and Instructional Studies int World, 2(1), 102-109.

Gurdal, A. (1991). Fen ogretiminde laboratuar etkinliginin basariya etkisi. Ozel Kultur Okullari Egitim Arastirma Gelistirme Merkezi Egitimde Yeni Arayislar I. Sempozyumu Egitimde Nitelik Gelistirme, İstanbul.

Hofstein, A., \& Lunetta, V. N., (1982). The role of the laboratory in science teaching: neglected aspects of research. Review of Educational Research, 52, 201-217.

Hofstein, A., \& Lunetta, V. N. (2004). The laboratory in science education: Foundations for the twenty-first century. Science Education, 88, 28-54, 2004.

Hofstein, A., Levi- 